\title{
Efficiency of capital taxation in an open economy: tax competition versus tax exportation
}

\author{
Wolf Wagner · Sylvester Eijffinger
}

Published online: 14 August 2008

(C) The Author(s) 2008. This article is published with open access at Springerlink.com

\begin{abstract}
Tax competition and tax exportation have contrary implications for the efficiency of capital taxation. We provide a simple condition for the dominance of either force, which depends on the mobility of foreign investment. We use this condition to evaluate the relative importance of both forces in the US and in the EU.
\end{abstract}

Keywords Tax competition · Tax exportation · Foreign ownership · Capital mobility

JEL Classification F2 $\cdot$ H12

\section{Introduction}

There is an ongoing debate about the consequences of the increasing mobility of capital for capital taxation. The standard argument is that when capital moves freely across borders, jurisdictions have an incentive to compete with each other in order to attract capital. This can lead to a "race to the bottom" and result in inefficiently low capital taxation. ${ }^{1}$

\footnotetext{
${ }^{1}$ For a survey of the substantial literature on tax competition, see Wilson (1999). There is also growing evidence for the existence of tax competition, see, for example, Brueckner and Saavedra (2001).

This paper has benefitted substantially from the comments of the editor, Jay Wilson, and three anonymous referees.

W. Wagner $(\bowtie)$

CentER, TILEC and Department of Economics, Tilburg University, Postbus 90153, 5000 LE Tilburg, The Netherlands

e-mail: wagner@uvt.nl

S. Eijffinger

CentER and Department of Economics, Tilburg University, Postbus 90153, 5000 LE Tilburg,

The Netherlands

e-mail: s.c.w.eijffinger@uvt.nl
} 
Recently, however, a counteracting force to tax competition has been emphasized. It arises because capital mobility facilitates cross-ownership of factors. Governments, maximizing the welfare of their residents, may then set higher source taxes on capital because a part of the tax burden falls on foreigners and can thus be exported. ${ }^{2}$

This paper presents a simple condition that allows us to compare the incentives for tax competition and tax exportation empirically. The condition shows that the dominance of either motive depends on the mobility of foreign investment. ${ }^{3}$ Using previous estimates of the tax elasticity of foreign direct investment (FDI), we apply this condition to the US and the EU. The results suggest that the tax competition motive may be dominant in the EU, while in the US tax exportation may be more important.

\section{Efficiency of capital taxation in an open economy}

Consider a small economy with a representative household who is endowed with an amount of capital $\bar{k}$. There is a representative domestic firm which has an amount of capital $k_{0}$ installed. However, this capital stock may adjust in response to changes in taxation. We denote the new capital stock (that is, after a potential tax change) with $k$ and the corresponding output level with $f(k)$. Foreigners own a share $\mu_{\mathrm{K}}$ of the domestic firm's capital stock and a share $\mu_{\mathrm{F}}$ of the country's fixed factor. ${ }^{4}$ The world interest rate is $r$.

In order to finance a public good, the government can raise a tax $\tau$ on the firm's capital. No other tax instruments are available. ${ }^{5}$ Denoting public good spending with $g$, we thus have

$$
g=\tau k
$$

The economy is initially in an equilibrium, in the sense that the domestic aftertax return on capital equals the world interest rate: $f^{\prime}-\tau=r$. Consider now a tax increase by the government. This reduces the domestic after-tax return on capital.

\footnotetext{
${ }^{2}$ Huizinga and Nielsen (1997) and Lee (1997) have shown that foreign ownership of profits and/or capital may lead to excessive taxation. In a tax competition model calibrated to the US and to European regions, Sørensen (2004) shows that foreign ownership has important implications for capital taxation. Empirical evidence for the tax exportation motive is provided in Wagner and Eijffinger (2004) for the US and in Huizinga and Nicodème (2008) for the EU.

${ }^{3}$ Huizinga and Nielsen (2002) also obtain a dominance condition for the tax elasticity of capital which is implied by full capital mobility. By contrast, in our condition, the tax elasticity is a parameter. Furthermore, we apply our model to the US and the EU. Wagner and Eijffinger (2004) study both motives under full financial integration and find that tax exportation incentives can lead to substantial taxes on capital. However, the approach does not allow taxation efficiency to be evaluated.

${ }^{4}$ Thus, we also allow for a tax exportation motive to arise from cross-ownership of the fixed factor. Relatedly, it has been shown that optimal taxation is affected when government services are enjoyed by nonresidents (Arnott and Grieson 1981) and, in the context of income redistribution when there are foreign immigrants that do not vote domestically (Leite-Monteiro 1997).

${ }^{5}$ The implications of tax exportation for the choice of tax instruments have been recently explored (e.g., Noiset 2003 and Braid 2005).
} 
Capital will then move abroad and we have $k<k_{0}$. There are proportional costs $\gamma$ of shifting capital abroad, which are given by

$$
\gamma(k)=\gamma_{0} \frac{k_{0}-k}{k_{0}}
$$

with $\gamma_{0}>0$. Note that the costs increase when $k$ falls. This implies that when more capital is shifted abroad, the (proportional) costs rise. This can be interpreted as the result of capital being heterogeneous and the more mobile parts of capital being shifted abroad first. Note also that the proportional costs of shifting an infinitesimal amount of capital abroad are zero.

The domestic household's consumption $c$ comes from the following sources. First, he obtains his share in the return on the country's fixed factor, $\left(1-\mu_{\mathrm{F}}\right)\left(f-f^{\prime}(k) k\right){ }^{6}$ Second, he obtains his share in the return on capital that is held domestically after capital relocation, $\left(1-\mu_{\mathrm{K}}\right)\left(f^{\prime}(k)-\tau\right) k$. Third, he obtains a return on capital shifted abroad. His share in the amount of capital moved abroad is $\left(1-\mu_{\mathrm{K}}\right)\left(k_{0}-k\right)$ and the rate of return on this is the world interest rate $r$ minus the capital relocation costs $\gamma$. Thus, this return is given by $\left(1-\mu_{\mathrm{K}}\right)(r-\gamma)\left(k_{0}-k\right)$. Fourth, he obtains the return on capital that was already held abroad at the beginning of the period, $r\left(\bar{k}-\left(1-\mu_{\mathrm{K}}\right) k_{0}\right)$. Return equalization requires that the return on domestic capital has to equal the return of capital shifted abroad: $f^{\prime}-\tau=r-\gamma$. Using this, we can summarize the household's consumption as

$$
c=(1-\mu)\left(f-f^{\prime} k\right)+r \bar{k}-\left(1-\mu_{\mathrm{K}}\right) \gamma k_{0}
$$

It thus consists of the household's claim to domestic profits, $(1-\mu)\left(f-f^{\prime} k\right)$, the world return on his total capital stock, $r \bar{k}$, minus a return loss on capital that was installed domestically, $\left(1-\mu_{\mathrm{K}}\right) \gamma k_{0}$.

Now consider a reduction in taxes. After-tax returns increase as a result and capital will move into the country and we have $k>k_{0}$. Denote the proportional costs of moving capital into the country by $\tilde{\gamma}>0$. Return equalization requires then that $f^{\prime}-\tau-\tilde{\gamma}=r$, that is, the after-tax return on domestic capital net of relocation costs equals the world interest rate. Analogous to (3), we can derive household's consumption as

$$
c=(1-\mu)\left(f-f^{\prime} k\right)+r \bar{k}+\left(1-\mu_{\mathrm{K}}\right) \tilde{\gamma} k_{0}
$$

We can see that the household now earns an excess return $f^{\prime}-\tau-r=\tilde{\gamma}>0$ on domestically installed capital. Note that for $\tilde{\gamma}=-\gamma$, consumption is identical to (3). Moreover, also the two return equalization conditions are then the same. Hence, if we set $\gamma:=-\tilde{\gamma}<0$ when $k>k_{0}$, we can use (3) and the corresponding return equalization condition for both tax increases and decreases. Note also that $\gamma$ in (2) is already defined such that $\gamma<0$ when $k>k_{0}$.

\footnotetext{
${ }^{6}$ We could also allow the household to have claims to a foreign fixed factor. However, this would not modify our analysis, since due to the small country assumption domestic taxation will not affect rents in the rest of the world.
} 
The government's optimization problem can be stated as maximizing the representative household's utility, consisting of the sum of the utility from private and public consumption $u(c)+v(g)$, subject to (1) and (3). In a closed economy, the only effect of capital taxation is an increase in public consumption at the expense of private consumption. Hence, issues of inefficient taxation and inefficient public good provision do not arise. However, in an open economy, the optimal taxation problem changes. First, an increase in the tax rate lowers leads to capital being shifted abroad $\left(k^{\prime}(\tau)<0\right)$. This erodes the tax base and reduces government's incentives to tax (tax competition motive). Second, the presence of foreign ownership $\left(\mu_{\mathrm{K}}, \mu_{\mathrm{F}}>0\right)$ lowers the domestic incidence of taxation. This increases the government's incentives to tax (tax exportation motive). ${ }^{7}$

We assume for our analysis that production is Cobb-Douglas with $f(l, k)=$ $l^{\alpha} k^{1-\alpha}$, where $l$ is the fixed factor. Proposition 1 states then that the tax competition motive dominates over the tax exportation motive (i.e., capital taxation and public good provision are inefficiently low $)^{8}$ if the tax elasticity of capital exceeds the degree of foreign ownership of capital adjusted for a factor $1+\phi$.

Proposition 1 There is under provision of the public good if and only if

$$
|\varepsilon|>\frac{\mu_{\mathrm{K}}}{1+\phi}
$$

where $\varepsilon=\left(k^{\prime}(\tau) / k\right) \tau$ is the tax elasticity of capital and

$$
\phi:=\left(\mu_{\mathrm{K}}-\mu_{\mathrm{F}}\right) \alpha \frac{r+\tau}{\tau}
$$

Proof The government's FOC is $u^{\prime}(c) c^{\prime}(\tau)+v^{\prime}(g) g^{\prime}(\tau)=0$. Hence, there is under provision of the public good (i.e., $v^{\prime}(g) / u^{\prime}(c)>1$ ) if and only if $-c^{\prime}(\tau) / g^{\prime}(\tau)>1$. From (1), we have $g^{\prime}(\tau)=k+\tau k^{\prime}(\tau)$. We write $k^{\prime}$ as shorthand for $k^{\prime}(\tau)$ in the following. From (3), we get that $c^{\prime}(\tau)=\left(1-\mu_{\mathrm{F}}\right)\left(f^{\prime}(k) k^{\prime}-f^{\prime \prime}(k) k k^{\prime}-f^{\prime}(k) k^{\prime}\right)-$ $\left(1-\mu_{\mathrm{K}}\right) \gamma^{\prime}(k) k^{\prime} k_{0}$, which simplifies to $c^{\prime}(\tau)=-\left(1-\mu_{\mathrm{F}}\right) f^{\prime \prime}(k) k k^{\prime}-\left(1-\mu_{\mathrm{K}}\right)$ $\gamma^{\prime}(k) k^{\prime} k_{0}$. We next derive an expression for $\gamma^{\prime}(k)$. We know that return equalization requires $r-\gamma=f^{\prime}-\tau$ whenever there is a tax change. Totally differentiating with respect to $\tau$ gives $-\gamma^{\prime}(k) k^{\prime}=f^{\prime \prime} k^{\prime}-1$. Using $f^{\prime \prime}(k)=-\alpha(1-\alpha) l^{\alpha} k^{-\alpha-1}=$ $-\alpha f^{\prime}(k) / k$ and the equilibrium condition $f^{\prime}(k)-\tau=r$ we get after rearranging $\gamma_{0}=\frac{\tau}{|\varepsilon|}-\alpha(r+\tau)$. Thus, we have $\gamma^{\prime}(k)=\left(-\frac{\tau}{|\varepsilon|}+\alpha(r+\tau)\right) \frac{1}{k_{0}}$. Inserting into

\footnotetext{
${ }^{7}$ The motive for taxation arises here from foreign ownership of domestic factors. Lee (2003) has shown that a government may also raise taxes on capital when domestic residents own immobile factors in other countries. This is because the subsequent outflow of capital may increase the return on immobile factors abroad, thus benefiting also domestic residents. This channel is not operative here because the small open economy takes returns earned abroad as given.

${ }^{8} \mathrm{We}$ focus on the dominance of the tax competition motive because a dominance of tax exportation does not necessarily imply inefficiencies as governments may simply distribute any excess revenue to the household. Alternatively, governments may provide tax breaks in order to offset the excessive tax burden on capital as in Wilson (1996).
} 
$c^{\prime}(\tau)$ gives $c^{\prime}(\tau)=-\left(1-\mu_{\mathrm{F}}\right) f^{\prime \prime}(k) k k^{\prime}+\left(1-\mu_{\mathrm{K}}\right)\left(\frac{\tau}{|\varepsilon|}-\alpha(r+\tau)\right) k^{\prime}$. Again, using $f^{\prime \prime}(k)=-\alpha f^{\prime}(k) / k$ and $f^{\prime}-\tau=r$ and furthermore that $k=k_{0}$ in equilibrium, we get $c^{\prime}(\tau)=\left(1-\mu_{\mathrm{F}}\right) \alpha(r+\tau) k^{\prime}+\left(1-\mu_{\mathrm{K}}\right)\left(\frac{\tau}{|\varepsilon|}-\alpha(r+\tau)\right) k^{\prime}$, which can be rearranged to $\left(\mu_{\mathrm{K}}-\mu_{\mathrm{F}}\right) \alpha(r+\tau) k^{\prime}+\left(1-\mu_{\mathrm{K}}\right) \frac{\tau}{|\varepsilon|} k^{\prime}$. Substituting $c^{\prime}(\tau)$ and $g^{\prime}(\tau)$ into the condition for under provision, $-c^{\prime}(\tau) / g^{\prime}(\tau)>1$, and rearranging, gives then (5).

The intuition for why the condition depends on the tax elasticity $|\varepsilon|$ and the foreign ownership of capital $\mu_{\mathrm{K}}$ is straightforward. A higher tax elasticity implies larger capital outflows following a tax increase, and thus strengthens the tax competition motive. A higher foreign ownership of capital reduces the domestic incidence of the capital tax when capital is not fully mobile, and increases the tax exportation motive.

The term $\phi=\left(\mu_{\mathrm{K}}-\mu_{\mathrm{F}}\right) \alpha(r / \tau+1)$ arises because a capital outflow raises the productivity of the remaining capital. This increases the pretax return on capital at the costs of a lower return for the fixed factor. If the foreign ownership shares of capital and the fixed factor are identical $\left(\mu_{\mathrm{K}}=\mu_{\mathrm{F}}\right)$, this effect cancels out. $\phi$ is then zero and the dominance condition becomes $|\varepsilon|>\mu_{\mathrm{K}}$. If the foreign ownership share for capital is larger, the domestic household loses more in terms of return on the fixed factor then he gains through a higher pretax return on domestic capital. Capital outflows are then relatively more costly for the country. This makes taxation less attractive, and hence $\phi>0$. Vice versa, if foreign ownership of capital is lower than foreign ownership of the fixed factor, taxation becomes more attractive and we have $\phi<0$.

Proposition 1 relates to public good under provision in the small economy. However, the result can easily be extended to the rest of the world. Suppose that the world consists of many small countries (each of them being identical to our small open economy). Suppose also that the world capital stock is fixed. Then world welfare is solely determined by the efficiency of public good provision. When condition (5) is in place, each country individually under provides the public good. Hence, there is also under provision of the public good on the world level, that is, countries would benefit from a coordinated rise in taxes.

\subsection{An empirical test}

In order to obtain an empirical test of (5), we assume that foreign ownership arises from FDI only (and hence there is no portfolio investment). The motivation is first that FDI is more closely related to the allocation of real capital, and thus to $k$ in our model. Second, focusing on FDI has the advantage that we can make use of the extensive empirical literature on the mobility of FDI.

Denote the total amount of (inward) FDI in the economy by FDI and the tax elasticity of (inward) FDI by $\varepsilon_{\mathrm{FDI}}=\left(\mathrm{FDI}^{\prime}(\tau) / \mathrm{FDI}\right) \tau$. The degree of foreign ownership of capital is hence $\mu_{\mathrm{K}}=\mathrm{FDI} / k$. Consider a small reduction in the tax $\tau$. This increases the domestic after-tax return on capital and causes an capital inflow. We assume that this capital inflow arises from a change in inward FDI only. The motivation is that the capital that is already installed is relatively fixed. Thus, the country may not reduce its outward FDI stock following a tax increase, as relocating the capital that is installed abroad may be too costly. 
Hence, we have $\varepsilon=\left(k^{\prime}(\tau) / k\right) \tau=\left(\mathrm{FDI}^{\prime}(\tau) / k\right) \tau=\varepsilon_{\mathrm{FDI}} \mu_{\mathrm{K}}$. Condition (5), therefore, simplifies to

$$
\left|\varepsilon_{\mathrm{FDI}}\right|>\frac{1}{1+\phi}
$$

Equation (7) shows that the tax competition motive will dominate only according to the tax elasticity of FDI, $\varepsilon_{\mathrm{FDI}}$, and the adjustment factor, $\phi$.

Note, however, that $\mu_{\mathrm{K}}$ enters (7) indirectly through its impact on $\left|\varepsilon_{\mathrm{FDI}}\right|$. To see this, consider the following thought experiment. Suppose that there exist two small economies that have a different $\mu_{\mathrm{K}}$ but are identical with respect to the model's other parameters. For example, one economy may simply have a larger foreign ownership share for historical reasons. As by assumption, both economies have the same tax elasticity of capital $|\varepsilon|$, a reduction in the capital tax rate would cause the same capital inflow (in absolute terms) in both economies. However, expressed as a percentage of total FDI, the inflow is smaller in the economy with the higher $\mu_{\mathrm{K}}$, and hence $\left|\varepsilon_{\mathrm{FDI}}\right|$ is smaller for this economy. Therefore, $\left|\varepsilon_{\mathrm{FDI}}\right|$ summarizes both tax competition and tax exportation effects. ${ }^{9}$

We first parameterize the factor $\phi=\left(\mu_{\mathrm{K}}-\mu_{\mathrm{F}}\right) \alpha \frac{r+\tau}{\tau}$. We interpret the fixed factor as labor, as is commonly done in macroeconomic calibrations. Most studies calibrate $\alpha$ to the labor income share (see, e.g., Gomme and Rupert 2008). For the US, this share is around 0.7 , and hence we set $\alpha=0.7$. The degree of foreign ownership of capital, $\mu_{\mathrm{K}}$, is set to $7 \%$ to match the ratio of inward FDI to the capital stock in the US. The degree of foreign ownership of labor, $\mu_{\mathrm{F}}$, is set to $0.1 \%$, which is the ratio of labor income of foreigners to total labor income in the US. ${ }^{10}$ This is likely to understate foreign ownership of fixed factors, as the other main fixed factor (land) has a higher foreign ownership. However, it turns out that our results are not particularly sensitive to sensible variations in the foreign ownership parameters (and also the income share parameter $\alpha$ ).

The results are, however, more sensitive to the ratio of the pretax return on capital and the capital tax rate, $\frac{r+\tau}{\tau}$. There is also more disagreement on this value. For the pretax return, typical values are between $7 \%$ and $13 \%$ (e.g., Gomme and Rupert 2008). Calibrations for the tax rate on capital income also range widely, from $25 \%$ to values up to $70 \%$ (such high rates are needed in order to calibrate empirically reasonable growth rates). ${ }^{11}$ Using these parameter ranges, we obtain a range for $\phi$ of $0.15<\phi<0.32$ or

$$
0.76<\frac{1}{1+\phi}<0.87
$$

\footnotetext{
${ }^{9}$ Condition (7) may have to be modified if tax increases are considered. This is because the elasticity of outward FDI will then determine the elasticity of the capital stock. However, at least for the US, this issue is of less importance because estimated inward and outward FDI elasticities are similar (see Hines 1999).

${ }^{10}$ Compensation of foreign workers in the US was 2.4 bln in the last quarter of 2006 and GDP was about $3400 \mathrm{bln}$. Using the labor income share of $\alpha=0.7$, this gives a foreign labor income share of about $2.4 /(3400 \cdot 0.7)=0.1 \%$.

${ }^{11}$ These income tax rates have to be transferred into capital tax rates. For example, for a pretax return of $7 \%$ and a capital income tax rate of $25 \%$, we obtain a capital tax rate of $7 \% \cdot 25 \%=1.75 \%$.
} 
Hines (1999) reports a consensus tax elasticity of -0.6 for FDI in the US. Similarly, in a survey of elasticity estimates consisting largely of studies of the US, de Mooij and Ederveen (2003) find a mean elasticity of FDI of $-0.7 .^{12}$ Thus, condition (7) is (just) violated, suggesting that public goods may be provided efficiently in the US.

Recent studies for the European Union have found higher elasticities. Gorter and Parikh (2000), Bénassy-Quéré et al. (2005), and Stöwhase (2008) report elasticities between -1.2 and -1.5 . $^{13}$ Condition (7) is then fulfilled, suggesting that the tax competition effect may be dominating in the EU, and hence capital taxes may be inefficiently low. ${ }^{14}$

\subsection{Qualifications}

First of all, it should be mentioned that there is still substantial uncertainty about the true magnitude of FDI elasticities (for a survey of FDI elasticities, see de Mooij and Ederveen 2003). This is for a variety of reasons, such as issues arising from the correct measurement of FDI and the relevant tax rates. In particular, it has been mentioned that the estimated FDI elasticities may overstate the true elasticities (e.g., Hines 1999, p. 309). One reason why this may be the case is that foreign investors habitually reinvest their earnings. As reinvested earnings appear as FDI, FDI and after-tax rates of return become positively correlated.

Our analysis has ignored foreign portfolio investment (FPI). This is basically because portfolio investment consists to a substantial part of financial investment and is therefore less related to the real capital stock in the economy to which our model relates. ${ }^{15}$ There is also a lack of empirical studies in the taxation literature that address the elasticity of portfolio investment and which we could use for our empirical test. In the following, we nevertheless want to clarify the potential role of portfolio investment in our setup.

Assume now that the foreign capital stock, $\mu_{\mathrm{K}} k$, consists of direct investment and (real) portfolio investment, i.e., $\mu_{\mathrm{K}} k=$ FDI + FPI. Denote the tax elasticity of FPI by $\varepsilon_{\mathrm{FPI}}=\left(\mathrm{FPI}^{\prime}(\tau) / \mathrm{FPI}\right) \tau$ and the relative shares of direct investment and portfolio investment by $\beta$ and $1-\beta$, respectively. It follows that the tax elasticity of capital $\varepsilon$ is

$$
\begin{aligned}
\varepsilon & =\left(k^{\prime}(\tau) / k\right) \tau=\left(\left(\mathrm{FDI}^{\prime}(\tau)+\mathrm{FPI}^{\prime}(\tau)\right) / k\right) \tau=\left(\varepsilon_{\mathrm{FDI}} \mathrm{FDI}+\varepsilon_{\mathrm{FPI}} \mathrm{FPI}\right) / k \\
& =\mu_{\mathrm{K}}\left(\beta \varepsilon_{\mathrm{FDI}}+(1-\beta) \varepsilon_{\mathrm{FPI}}\right)
\end{aligned}
$$

\footnotetext{
${ }^{12}$ Most studies report tax rate elasticities (semielasticities), which can be transformed into elasticities by multiplying with the capital tax rate. We assume a rate of $30 \%$ for this calculation.

${ }^{13}$ Büttner (2002) reports a somewhat lower estimate between -0.5 and -0.9 .

${ }^{14}$ Note that under provision of public goods in the EU relative to the US does not imply lower taxation in the EU since preferences for public consumption may be larger in the EU.

${ }^{15}$ Suppose, for example, that the government (unexpectedly) raises the capital tax rate. This reduces the price of domestic equity and thus the value of FPI. The capital stock of domestic firm, however, may be unchanged.
} 
Inserting into (5) gives

$$
\beta\left|\varepsilon_{\mathrm{FDI}}\right|+(1-\beta)\left|\varepsilon_{\mathrm{FPI}}\right|>\frac{1}{1+\phi}
$$

Hence, in the presence of portfolio investment, the relevant elasticity is the weighted average of the FDI and FPI elasticities, where weights are given by their relative shares in total foreign investment. For the US and for many other industrialized countries, FDI and FPI are of a similar magnitude (e.g., Lane and Milesi-Ferretti 2001, suggesting that this would be roughly the unweighted average of both elasticities. Thus, our results will only be biased if the FPI elasticity (for real capital) differs from the FDI elasticity.

We have also presumed that tax reductions affect the domestic capital stock only through an increase in inward FDI but not through a reduction in outward FDI. This is obviously an extreme assumption. Take the other extreme and assume that outward FDI is equally sensitive to (domestic) tax reductions as inward FDI. Then the capital elasticity of taxation would effectively double. As a result, the left-hand side of condition (7) (which represents the capital elasticity) becomes twice as large. This would strengthen the tax competition motive and suggest that an efficient provision of public goods may also be a problem for the US.

For our analysis, we have interpreted the fixed factor as labor and have assumed that labor is immobile. However, labor becomes increasingly mobile across borders. When labor is mobile but governments still take their citizens into account when they reside abroad (as, for example, in Leite-Monteiro 1997), the tax competition motive may be weakened. This is because a capital outflow following a tax increase becomes then less costly for the country, since the resulting reduction in the labor productivity hurts the country less since its citizens can move abroad. A further reason why tax competition may become less attractive due to labor mobility is that the higher perceived benefits it creates for a country (in terms of higher wages and/or social transfers) tend to increase immigration. Since domestic residents then have to share the benefits with the immigrants, they may vote against lower taxes (Kessler, Lülfesmann, Myers 2002).

Another simplification we have made is that the fixed factor consists only of labor. It is straightforward to extend the analysis to include other fixed factors. Suppose, for example, that there are two fixed factors, $l_{1}$ and $l_{2}$, and that production is still CobbDouglas: $f\left(l_{1}, l_{2}, k\right)=l_{1}^{\alpha_{1}} l_{2}^{\alpha_{2}} k^{1-\alpha_{1}-\alpha_{2}}$. Define with $r=l_{2} / l_{1}$ the ratio of the fixed factors. We can then rewrite production as $f=r^{\alpha_{2}} l_{1}^{\alpha_{1}+\alpha_{2}} k^{1-\alpha_{1}-\alpha_{2}}$. The proportional term $r^{\alpha_{2}}$ can be ignored and for $\alpha:=\alpha_{1}+\alpha_{2}$, we get $f(l, k)=l^{\alpha} k^{1-\alpha}$.

In order to compute $\alpha$ (which is needed for the computation of $\phi$ ) in the presence of more than one fixed factor, we can thus simply add the income shares of all fixed factors. As before, the foreign ownership share of the fixed factor can be obtained by dividing the fixed factor income that is attributable to foreigners by the total income of the fixed factors, $f-f^{\prime}(k) k$. If one assumes that factors are remunerated according to their marginal product, their income shares will be proportional to their $\alpha$ since we have assumed Cobb-Douglas properties. The total foreign ownership share of the 
fixed factor is then

$$
\mu_{\mathrm{F}}=\frac{\alpha_{1} \mu_{\mathrm{F}_{1}}+\alpha_{2} \mu_{\mathrm{F}_{2}}}{\alpha_{1}+\alpha_{2}}
$$

i.e., the sum of the foreign ownership shares of the fixed factors weighted with their respective income shares.

Typically, land is considered as the second fixed factor. Incorporating land creates two offsetting effects on the tax exportation motive through its impact on $\phi(6)$. On one hand, foreign ownership of land is likely to be higher than foreign ownership of labor. Thus, $\mu_{\mathrm{F}}$ increases and the total burden borne by the domestically owned fixed factors following a capital outflow falls ( $\phi$ decreases when $\mu_{\mathrm{F}}$ increases). On the other hand, also the total income share that is attributable to fixed factors, $\alpha$, rises. This has the effect of raising the share of the tax burden that is borne by fixed factors. As the overall foreign ownership share of the fixed factors is likely to be still lower than for capital, the domestic burden of a tax rise becomes higher ( $\phi$ increases when $\alpha$ increases and $\mu_{\mathrm{F}}<\mu_{\mathrm{K}}$ ). The implications for our empirical test, however, are limited. This is because as already mentioned earlier, $\phi$ is not very sensitive to variations in $\mu_{\mathrm{F}}$ and $\alpha$.

Another issue is that a substantial tax burden of corporations comes in the form of property taxes, which tax capital and land income at the same rate (as modeled in Wilson 1995, and Braid 1996). The tax exportation motive will be stronger for a property tax than for a tax that is raised solely on capital. This is because it also redistributes land income from foreigners to the domestic household. Thus, compared to a capital tax, under provision of public goods is less likely when property taxes are used.

Open Access This article is distributed under the terms of the Creative Commons Attribution Noncommercial License which permits any noncommercial use, distribution, and reproduction in any medium, provided the original author(s) and source are credited.

\section{References}

Arnott, R., \& Grieson, R. (1981). Optimal fiscal policy for a state or local government. Journal of Urban Economics, 9, 23-48.

Bénassy-Quéré, A., Fontagné, L., \& Lahrèche-Révil, A. (2005). How does FDI react to corporate taxation? International Tax and Public Finance, 12, 583-603.

Braid, R. (1996). Symmetric tax competition with multiple jurisdictions in each metropolitan area. American Economic Review, 86, 1279-1290.

Braid, R. (2005). Tax competition, tax exporting and higher-government choice of tax instruments for local governments. Journal of Public Economics, 89, 1789-1821.

Brueckner, J., \& Saavedra, L. (2001). Do local governments engage in strategic property-tax competition? National Tax Journal, 54, 203-230.

Büttner, T. (2002). The impact of taxes and public spending on the location of FDI: evidence from FDIflows within Europe. ZEW discussion paper no. 02-17.

de Mooij, R., \& Ederveen, S. (2003). Taxation and foreign direct investment: a synthesis of empirical research. International Tax and Public Finance, 10, 673-693.

Gomme, P., \& Rupert, P. (2008, forthcoming). Theory, measurement, and calibration of macroeconomic models. Journal of Monetary Economics.

Gorter, J., \& Parikh, A. (2000). How mobile is capital within the European Union? CPB Research Memorandum no. 172. 
Hines, J. (1999). Lessons from behavioral responses to international taxation. National Tax Journal, 52, 305-322.

Huizinga, H., \& Nicodème, G. (2008, forthcoming). Foreign ownership and corporate income taxation: an empirical evaluation. European Economic Review.

Huizinga, H., \& Nielsen, S. B. (1997). Capital income and profit taxation with foreign ownership of firms. Journal of International Economics, 42, 149-165.

Huizinga, H., \& Nielsen, S. B. (2002). The coordination of capital income and profit taxation with crossownership of firms. Regional Science and Urban Economics, 32, 1-26.

Kessler, A., Lülfesmann, C., \& Myers, G. (2002). Redistribution, fiscal competition, and the politics of economic integration. Regional Science and Urban Economics, 32, 1-26.

Lane, P. R., \& Milesi-Ferretti, G. (2001). The external wealth of nations: measures of foreign assets and liabilities for industrial and developing countries. Journal of International Economics, 55, 263-294.

Lee, K. (1997). Tax competition with imperfectly mobile capital. Journal of Urban Economics, 42, 222242.

Lee, K. (2003). Factor ownership and governmental strategic interaction. Journal of Public Economic Theory, 5, 345-361.

Leite-Monteiro, M. (1997). Redistributive policy with labour mobility across countries. Journal of Public Economics, 65.

Noiset, L. (2003). Is it tax competition or tax exporting? Journal of Urban Economics, 54, 639-647.

Sørensen, P. (2004). International tax coordination: regionalism versus globalism. Journal of Public Economics, 88, 1187-1214.

Stöwhase, S. (2008, forthcoming). Tax differentials and sector specific foreign direct investment: empirical evidence from the EU. Finanzarchiv.

Wagner, W., \& Eijffinger, S. (2004). Capital taxation with foreign ownership and imperfectly mobile capital. Mimeo, Tilburg University.

Wilson, J. (1995). Mobile labor, multiple tax instruments, and tax competition. Journal of Urban Economics, 38, 333-356.

Wilson, J. (1996). The tax treatment of imperfectly mobile firms: rent-seeking, rent-protection, and rent destruction. In R. Feenstra, G. Grossman, \& D. Irwin (Eds.), The political economy of trade policy: essays in honor of Jagdish Bhagwati. Cambridge: MIT Press.

Wilson, J. D. (1999). Theories of tax competition. National Tax Journal, 52, 269-304. 